Article

\title{
Coordinated Control of a Wind-Methanol-Fuel Cell System with Hydrogen Storage
}

\author{
Tiejiang Yuan ${ }^{1}$, Qingxi Duan ${ }^{1}$, Xiangping Chen ${ }^{2, *}$ (D) , Xufeng Yuan ${ }^{2}$, Wenping Cao ${ }^{3}$, \\ Juan $\mathrm{Hu}^{4}$ and Quanmin $\mathrm{Zhu}^{5}$ \\ 1 Electrical Engineering School, Dalian University of Technology, Dalian 116024, China; \\ ytj1975@dlut.edu.cn (T.Y.); dqx1991@163.com (Q.D.) \\ 2 Electrical Engineering School, Guizhou University, Guiyang 550025, China; ee.xfyuan@gzu.edu.cn \\ 3 School of Engineering \& Applied Science, Aston University, Birmingham B4 7ET, UK; w.p.cao@aston.ac.uk \\ 4 China Electric Power Research Institute, Beijing 102249, China; juanhoo@epri.sgcc.com.cn \\ 5 Department of Engineering, Design and Mathematics, University of the West of England, \\ Bristol BS16 1QY, UK; Quan.Zhu@uwe.ac.uk \\ * Correspondence: ee.xpchen@gzu.edu.cn
}

Received: 18 October 2017; Accepted: 30 November 2017; Published: 4 December 2017

\begin{abstract}
This paper presents a wind-methanol-fuel cell system with hydrogen storage. It can manage various energy flow to provide stable wind power supply, produce constant methanol, and reduce $\mathrm{CO}_{2}$ emissions. Firstly, this study establishes the theoretical basis and formulation algorithms. And then, computational experiments are developed with MATLAB/Simulink (R2016a, MathWorks, Natick, MA, USA). Real data are used to fit the developed models in the study. From the test results, the developed system can generate maximum electricity whilst maintaining a stable production of methanol with the aid of a hybrid energy storage system (HESS). A sophisticated control scheme is also developed to coordinate these actions to achieve satisfactory system performance.
\end{abstract}

Keywords: coordinated control; energy storage; fuel cell; hydrogen; methanol production; wind power

\section{Introduction}

In order to curb global warming, international efforts have been devoted to developing renewable energy sources as well as utilizing conventional energy in a cleaner way. Wind energy, as a renewable source of energy, attracts much attention from research community and industry. As the largest $\mathrm{CO}_{2}$ emitter, China had installed 150 million $\mathrm{kW}$ of wind turbines by the end of 2016 [1]. However, wind power is intermittent and its increasing penetration in the power network can create power stability issues. Therefore, much research is focused on the integration of wind energy in the power system for a resilient energy supply [2-5]. On the other hand, China is also the world's largest coal producer. Coal is a primary source of energy and accounts for $90 \%$ of China's $\mathrm{CO}_{2}$ emissions from fossil fuels [6]. How to use coal in a cleaner way is always a challenge facing the successive Chinese governments.

Methanol is a clean-burning liquid that requires only minor modifications to existing engines and fuel-delivery infrastructure. Manufacturing it could even make use of carbon dioxide, which is the main cause for global warming. While methanol's benefits have long been understood, recent advances in methanol synthesis and methanol fuel cells could make this fuel even more attractive [7]. Conventionally, methanol is a by-product of mining coal through a hydrocarbylation reaction. In this process, 1.526 times of $\mathrm{CO}_{2}$ could be produced with one unit of methanol. This has led to a significant increase in $\mathrm{CO}_{2}$ emissions to the environment. In order to tackle this issue, a new representative 
process has been developed [8] to produce methanol from hydrogen, oxygen and coal which is used in this study.

Energy storage is important to maintain the stable operation of energy systems. Reference [9] presented a new energy storage design to support energy flow in a hybrid wind-hydrogen system. Reference [10] proposed a hybrid energy system consisting of a wind turbine generator, a fuel cell with a water electrolyser and a battery energy storage system. Typically, these energy components are divided into two groups and two PI controllers were used to manage energy flow. By combining wind energy with fuel cells, reference [11] discussed the feasibility of a hybrid system satisfying residential demands when connected to the power grid. Reference [12] proposed an optimal method for sizing a grid-connected wind farm with a hydrogen system. Fuel cell systems with wind energy were also investigated in references [13-16] in order to find an optimal structure in the hybrid system. New concepts for optimal applications for wind energy were proposed $[17,18]$. These hybrid energy systems were integrated with integrating wind energy and coal-based methanol production, so as to provide an effective method to utilize local energy resources. Energy management and control methods in multi energy sources are critically important also important. Fuzzy logic control is a popular option for hybrid energy systems. Reference [19] presented a particle swarm-based fuzzy logic control for a hybrid wind-fuel cell-battery system to decrease total harmonic distortion of the power sources. A maximum power point tracking (MPPT) algorithm was used in a wind-fuel cell system [20] to meet variable load. Reference [21] adopted a probability distribution function to manage a wind-fuel cell-turbine with energy storage. The test results for different scenario of load or demand uncertainty. These systems are effective but have their limitations. It is the author's review that using systematic approaches to integrate the developed techniques will increase multiple functions in the loop of energy generation, utilization, operation, clean environment and so on.

The research project uses Xinjiang, the large territory province in China, as a case background. It is an important energy base in China, it connects advanced provinces in East China eastward, and links to the Central Asia countries westward. Xinjiang is regarded as a strategic hub on the "Silk Road Economic Belt". It is rich in coal resources and wind energy, which is a perfect match for the project as generated electricity from wind can be used for water electrolysis to produce hydrogen and oxygen. Xinjiang has been one of the five national integrated energy bases [22,23]. Therefore, how to effectively utilise coal sources and wind energy in Xinjiang is one of the crucial issues in China's national agenda. In national perspective, China has been a major contributor to global warming and thus is committed to play a significant role to cut down its $\mathrm{CO}_{2}$ emissions. In June 2014, China proposed a radical measure for managing its energy consumption and for developing renewable energy technologies. China has become the largest renewable producer in 2016, according to British Petroleum Statistical Review of World Energy [24].

This study proposes a hybrid system including a wind turbine, hydrogen/oxygen storage tanks through water electrolysis, a coal-base methanol device and a fuel cell. In this multi-source system, energy is managed into different forms: kinetic energy in a turbine; chemical energy in hydrogen/oxygen and fuel cells; electrical energy in the wind turbine/generators and the fuel cells. The hydrogen production through water electrolysis and the charging/discharging of the fuel cells provide flexibility when the intermittent wind power cannot match the energy requested. Meanwhile, methanol production with the new technology reduces the $\mathrm{CO}_{2}$ emission for the system $[17,25]$ which also in turn increase the revenue from the carbon trading scheme according to the national policy $[26,27]$. In this system, energy flow is managed by a coordinated control strategy. It determines the electricity generation and methanol production, with a target of maximising utilisation of wind energy. The feasibility and the performance of the strategy are tested through modeling and simulation in the MATLAB/Simulink environment. The novelty and contribution of the study are listed below.

(1) Integration wind energy into the grid has resulted in degradation of the inertia response, which in turn seriously affects the stability of the power system's frequency. This problem can be solved by 
using an active power reserve to stabilize the frequency. Hydrogen/oxygen fuel cell technology is one of solution as a power reserve for this purpose.

(2) Hydrogen/oxygen production from water electrolysis could provide the resource for fuel cell applications. As typical electricity-to-hydrogen conversion devices, electrolysers are regarded as deferrable loads with the ability to operate under a flexible schedule on the demand side.

(3) The coal-based methanol production is one of research challenges of clean energy applications of fossil fuels. This study adopts a "greener" process. The oxygen is fed to the gasifier as the gasification agent and then the hydrogen is mixed with the CO-rich gas to adjust $\mathrm{H}_{2} / \mathrm{CO}$ so as to produce methanol. However, it requires local supplies of hydrogen/oxygen continuously. Therefore, this kind of applications are limited. However, specific geometry advantages of Xinjiang province is perfect for this kind of applications.

(4) This innovative application integrates wind power, hydrogen from water electrolysis, hydrogen/oxygen fuel cells and a coal-based methanol production by a "greener" process. The system proposed has advantages of both the renewable sources and sustainable coal industries in China. Methanol receives hydrogen/oxygen to balance the local loads and to increase the overall profits. However, the hybrid construct would increase the system complexity. Therefore, it is necessary to investigate the possible energy management strategy and control mechanism before physical complicated system is build up.

The rest of the main studies are arranged as follows: Section 2 introduces the configuration of the hybrid system; Detailed discussion associated with the control scheme is carried out for energy management of this system; Section 3 provides the simulation outcomes and analysis; Section 4 summarises the main findings and suggests future work.

\section{The Hybrid System and Its Control Scheme}

The schematic diagram of the system is shown in Figure 1. The system includes a doubly-fed induction generator (DFIG) of a wind turbine, coal-based methanol production sub-system, a water electrolyser for hydrogen production, hydrogen and oxygen storage tanks, fuel cells, a DC link, DC / AC or AC/DC converters. The coal chemical process comprises gasification, mixing, purification, reaction, separation and rectification.

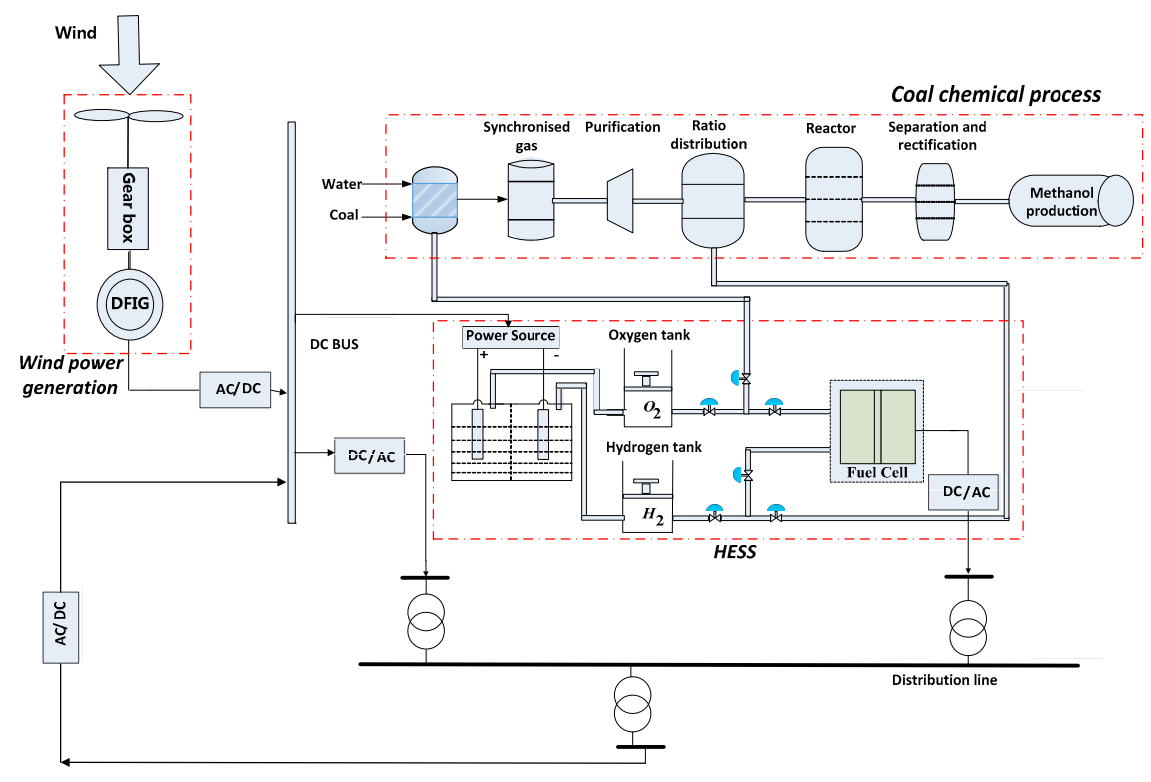

Figure 1. Schematic diagram of the proposed system. 
This system is operated on the following basis:

i. Wind power is used to generate electricity for supplying the grid and for producing hydrogen through water electrolysis.

ii. Normally, the generated electricity is fed into the power grid. If the wind power is plenty, the additional power is used for water electrolysis and the energy is stored in hydrogen.

iii. Hydrogen and oxygen produced are stored in separate tanks and are controlled to be within a range (upper limit 90\% and lower limit 20\%).

iv. Fuel cells absorb hydrogen and generate electricity to supply the grid.

v. Methanol is produced constantly (from coal, hydrogen and oxygen) at a set value regardless of wind power input.

Figure 2 shows the operation of the proposed system.

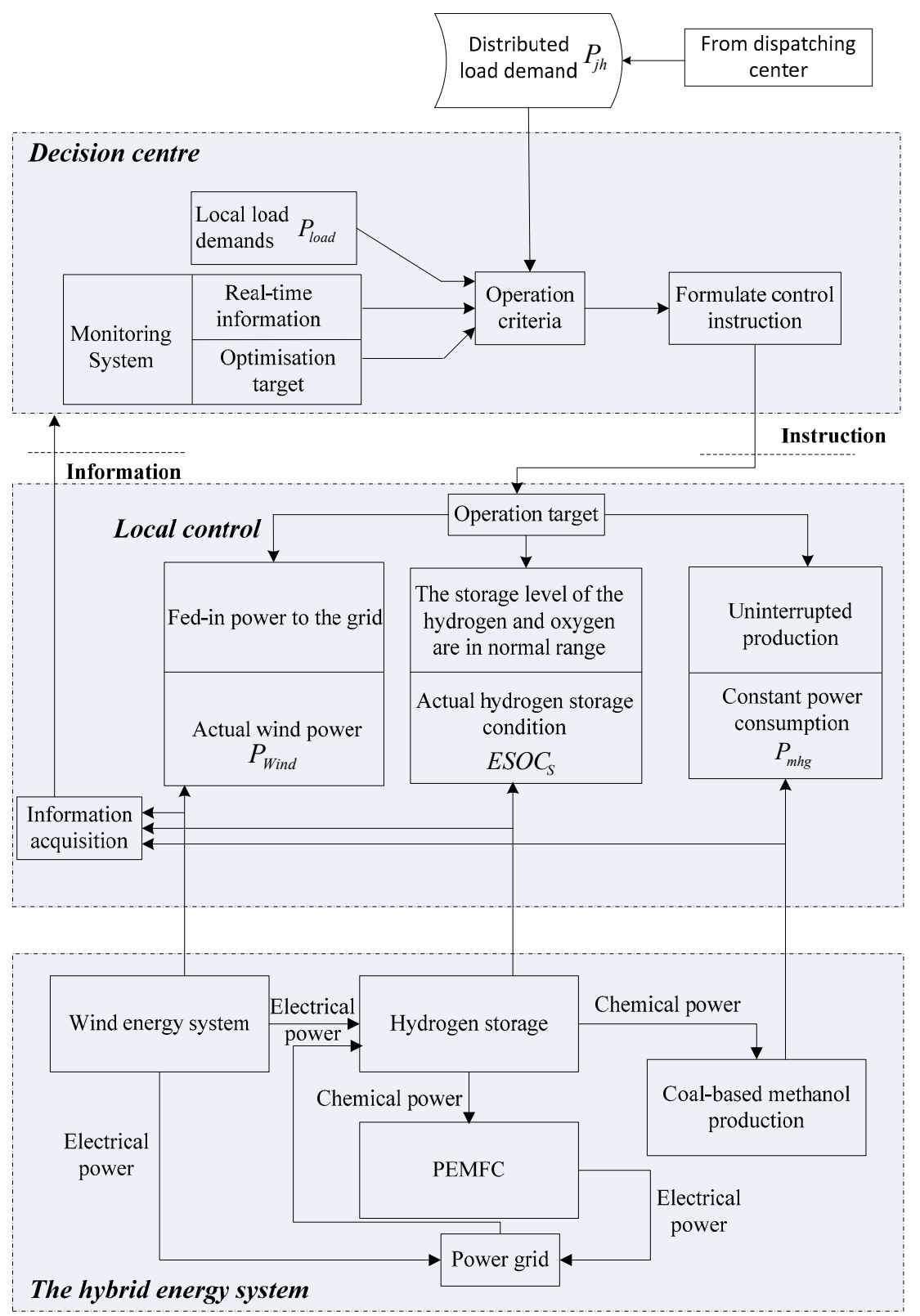

Figure 2. The proposed scheme with coordinated control. 


\subsection{State Index of the Hybrid Energy Storage System (HESS)}

In this paper, the HESS consists of a water electrolyser, a hydrogen and an oxygen tank, and fuel cells. The energy flow in the HESS is bi-direction. However, methanol production is single direction and cannot be fed back. Therefore, coal-based methanol production is not involved in the storage system in this study. In the HESS, the equivalent state of charge (ESOC) is evaluated by the state of the hydrogen and oxygen tanks:

$$
E S O C=\frac{p_{\text {vre }}}{p_{\text {cap }}}
$$

where $p_{\text {vre }}$ and $p_{\text {cap }}$ are the current pressure and full pressure of the tanks, respectively. Based on the average weighting method, the ESOC is calculated as follows:

$$
\begin{gathered}
E S O C_{H}=\frac{p_{\text {Hre }}}{p_{\text {Hcap }}} \\
E S O C_{O}=\frac{p_{\text {Ore }}}{p_{\text {Ocap }}} \\
E S O C_{S}=\frac{E S O C_{H} \times V_{\text {Hcap }}+E S O C_{O} \times V_{\text {Ocap }}}{V_{\text {Hcap }}+V_{\text {Ocap }}}
\end{gathered}
$$

where $E S O C_{H}$ is the $E S O C$ level of the hydrogen storage tank, $p_{H r e}$ is the pressure of the hydrogen tank, $p_{\text {Hcap }}$ is the full pressure of the hydrogen tank, ESOC $O$ is the ESOC level of the oxygen tank, $p_{\text {Ore }}$ is the pressure of the oxygen tank, $p_{\text {Ocap }}$ is the full pressure of the oxygen tank, $V_{\text {Hcap }}$ and $V_{\text {Ocap }}$ are the volumes of hydrogen and oxygen tanks, respectively.

In order to operate the HESS effectively, the indicators of $E S O C_{H}, E S O C_{O}, E S O C_{S}$ should be controlled within reasonable range. Basically, they are divided into two intervals and three situations, as shown in Figure 3. Each interval can be determined by Equation (5):

$$
\left\{\begin{array}{l}
\text { Normal interval : } E S O C_{X \_ \text {min }} \leq E S O C_{X} \leq E S O C_{X \_ \text {max }}, N_{H_{2} O}=N_{f c}+N_{m h g} \\
\text { Warning interval }:\left\{\begin{array}{l}
E S O C_{X}<E S O C_{X \_ \text {min }}, N_{H_{2} O}>N_{f c}+N_{m h g}, X=H, O, S \\
E S O C_{X}>E S O C_{X \_ \text {max }}, N_{H_{2} O}<N_{f c}+N_{m h g}
\end{array}\right.
\end{array}\right.
$$

where $E S O C_{X_{-} \text {min }}$ represents the minimal of ESOC and $X$ represents hydrogen, oxygen and HESS states, respectively. ESOC $X_{-}$max is the maximal of hydrogen, oxygen and HESS. $\mathrm{N}_{\mathrm{H}_{2} \mathrm{O}}$ is the hydrogen flow rate in water electrolyser. $N_{f c}$ is the hydrogen flow rate in the fuel cell. $N_{m h g}$ is the hydrogen flow rate used in coal chemical system when producing methanol.

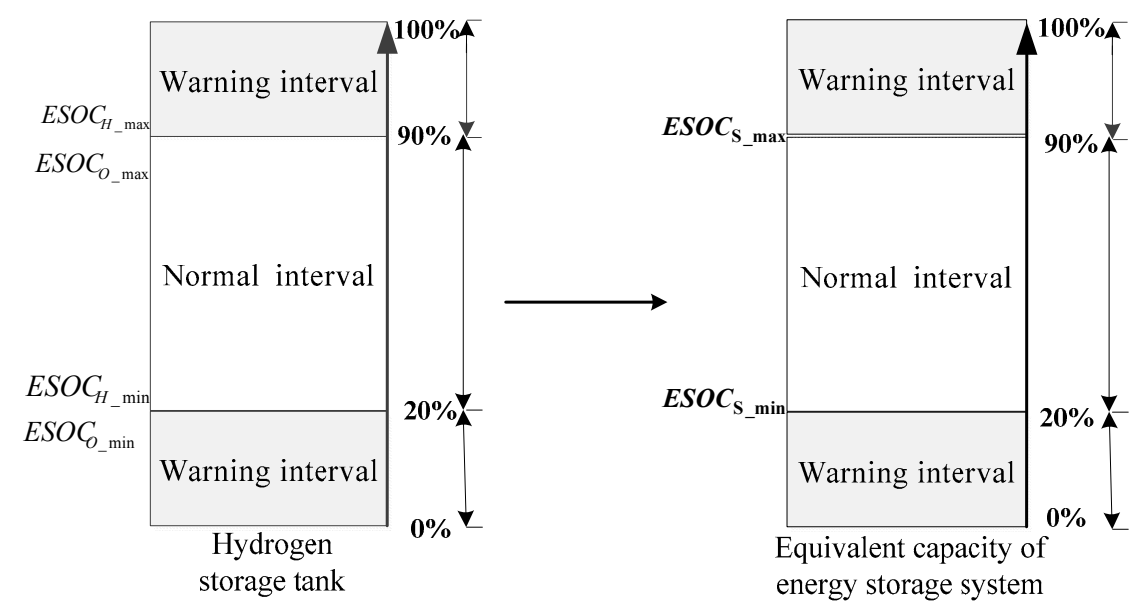

Figure 3. The capacity range of the HESS. 
When the tank or ESOC level is in the normal range, the coal chemical system operates normally to produce methanol. The ideal operation state of the system is that hydrogen generated by the water electrolysis is equal to the sum of hydrogen consumption in the methanol production and in the fuel cells discharging while the ESOC of the HESS is still within the normal range.

In the control scheme, $E S O C_{S}$ is considered as the priority factor in the operation. And the relationship among the wind power output $P_{\text {wind }}$, the cluster power dispatch demand $P_{j h}$, local load demand $P_{\text {load }}$ is defined as follows:

(1) When $E S O C_{S}>E S O C_{S_{-} \text {max }}$, let $i=1$ and $P_{\text {re }}^{(i)}=P_{\text {wind }}-\left(P_{\text {load }}+P_{\text {jh }}\right)$

(2) When $E S O C_{S_{-} \text {min }} \leq E S O C_{S} \leq E S O C_{S_{-} \max }$, let $i=2$ and $P_{r e}^{(i)}=P_{\text {wind }}-P_{\text {load }}$

(3) When $E S O C_{S}<E S O C_{S_{-} \text {min }}$, let $i=3$ and $P_{r e}^{(i)}=P_{\text {wind }}$

\subsection{Operation Scheme of the Hybrid System}

The system converts energy between electrical, chemical and mechanical. Hydrogen/oxygen generation is an integral part of the energy flow. The processes involve several reactions as follows [28,29]:

Water electrolysis: $\mathrm{H}_{2} \mathrm{O} \rightarrow \frac{1}{2} \mathrm{O}_{2}+2 \mathrm{H}^{+}+2 e^{-}$, therefore, $n\left(\mathrm{H}_{2}\right): n\left(\mathrm{O}_{2}\right)=2: 1$

Coal based methanol production: $\mathrm{CO}+2 \mathrm{H}_{2}=\mathrm{CH}_{3} \mathrm{OH}$, therefore:

$$
n\left(H_{2}\right): n\left(O_{2}\right)=1: 1
$$

Electrochemical reactions in a fuel cell: $\mathrm{H}_{2}+\frac{1}{2} \mathrm{O}_{2} \rightarrow \mathrm{H}_{2} \mathrm{O}$, therefore, $n\left(\mathrm{H}_{2}\right): n\left(\mathrm{O}_{2}\right)=1: 0.5$

For the constant production of methanol at set power $P_{m h g}$, the hydrogen and oxygen are the same. The flow rate of hydrogen $N_{m h g}$ and power demand $P_{r e}^{(i)}$ are given in Table 1.

Table 1. Interval scheme of power $P_{r e}^{(i)}$ with the flow rate $N_{\mathrm{H}_{2}}$.

\begin{tabular}{ccccc}
\hline & $\mathbf{f l}_{\mathbf{1}}$ & $\mathbf{f l}_{\mathbf{2}}$ & $\mathbf{f l}_{3}$ & $\mathbf{f l}_{\mathbf{4}}$ \\
\hline$P_{r e}^{(i)}$ & $\left(0, P_{\text {mhg }}\right)$ & {$\left[P_{m h g}, 2 P_{\text {mhg }}\right]$} & $\left(2 P_{\text {mhg }}, 4 P_{\text {mhg }}\right]$ & $\left(4 P_{m h g},+\infty\right)$ \\
$N_{\mathrm{H}_{2}}$ & $\left(0, N_{\text {mhg }}\right)$ & {$\left[N_{\text {mhg }}, 2 N_{\text {mhg }}\right]$} & $\left(2 N_{\text {mhg }}, 4 N_{\text {mhg }}\right]$ & $\left(4 N_{\text {mhg }},+\infty\right)$ \\
\hline
\end{tabular}

When $P_{\mathrm{H}_{2} \mathrm{O}}$ and $\mathrm{N}_{\mathrm{H}_{2} \mathrm{O}}$ are in interval $\gamma_{1}$, hydrogen from water electrolysis is not sufficient to sustain the required methanol production, as a result, the stored hydrogen in the tank is also consumed and ESOC $S$ slowly reduces. When $P_{\mathrm{H}_{2} \mathrm{O}}$ and $\mathrm{N}_{\mathrm{H}_{2} \mathrm{O}}$ are in interval $\gamma_{2}$, the generated hydrogen is more than the needed for methanol. Extra hydrogen is consumed by fuel cells to generate electricity. In $\gamma_{3}$ or $\gamma_{4}$, when the hydrogen is much more than needed, extra hydrogen is used for fuel cells and methanol and increasing tank levels. Table 2 gives detailed explanations.

Table 2. Operational regulation for different scenarios.

\begin{tabular}{|c|c|c|c|}
\hline \multicolumn{2}{|c|}{ Indicator } & \multirow{2}{*}{$\begin{array}{l}\text { Scenario } \\
E S O C_{S} \text { is over the upper limit. } \\
\text { The wind power is insufficient to } \\
\text { satisfy both local demands and cluster } \\
\text { power requested by the grid. }\end{array}$} & \multirow{2}{*}{$\begin{array}{l}\text { Action } \\
\text { The total wind power is fed into the grid. } \\
\text { The fuel cells discharge. Water electrolysis } \\
\text { suspends, } P_{\mathrm{H}_{2} \mathrm{O}}=0 \text {. }\end{array}$} \\
\hline \multirow{3}{*}{$\begin{array}{c}i=1 \\
P_{r e}^{(i)}= \\
P_{\text {wind }}- \\
\left(P_{\text {load }}+P_{j h}\right)\end{array}$} & $P_{r e}^{(i)}<0$ & & \\
\hline & $P_{r e}^{(i)}=0$ & $\begin{array}{l}E S O C_{S} \text { is over the upper limit. } \\
\text { The wind power is sufficient to satisfy } \\
\text { both local and cluster power, the rest } \\
\text { of the wind power is equal to } 0 \text {. }\end{array}$ & $\begin{array}{l}\text { The wind power is completely transferred to } \\
\text { the grid. Water electrolysis suspends, } P_{\mathrm{H}_{2} \mathrm{O}}=0 \text {. }\end{array}$ \\
\hline & $P_{r e}^{(i)} \in Y_{1}$ & $\begin{array}{l}E S O C_{S} \text { is over the upper limit. } \\
\text { The wind power is sufficient to satisfy } \\
\text { both local and cluster power. The rest } \\
\text { of the wind power is within } Y_{1} \text {. }\end{array}$ & $\begin{array}{l}\text { The wind power fed into the grid is set } \\
\left(P_{\text {load }}+P_{j h}\right), P_{\mathrm{H}_{2} \mathrm{O}}=P_{r e}^{(i)}\end{array}$ \\
\hline
\end{tabular}


Table 2. Cont.

\begin{tabular}{|c|c|c|c|}
\hline & Indicator & Scenario & Action \\
\hline & $P_{r e}^{(i)} \in\left(Y_{2} \cup Y_{3} \cup Y_{4}\right)$ & $\begin{array}{l}E S O C_{S} \text { is over the upper limit. } \\
\text { The wind power is sufficient to satisfy } \\
\text { both local and cluster power. The rest } \\
\text { of the wind power is within } Y_{2} \text { or } Y_{3} \\
\text { or } Y_{4} \text {. }\end{array}$ & $\begin{array}{l}\text { The wind power is used for water electrolysis } \\
\text { which provide the hydrogen for methanol } \\
\text { production. } P_{\mathrm{H}_{2} \mathrm{O}}=P_{r e}^{(i)} \text { and the rest wind } \\
\text { power is transferred to the grid. }\end{array}$ \\
\hline \multirow[b]{2}{*}{$\begin{array}{c}i=2 \\
P_{r e}^{(i)}= \\
P_{\text {wind }}-P_{\text {load }}\end{array}$} & $P_{r e}^{(i)}<0$ & $\begin{array}{l}E S O C_{S} \text { is within the normal range. } \\
\text { The wind power is insufficient to } \\
\text { satisfy the local demands. }\end{array}$ & $\begin{array}{l}\text { The total wind power is fed into the grid. } \\
\text { The fuel cells discharge with } P_{f c}=\left|P_{r e}^{(i)}\right| \\
\text { Water electrolysis process suspends, } P_{\mathrm{H}_{2} \mathrm{O}}=0 \text {. }\end{array}$ \\
\hline & $\begin{array}{c}P_{r e}^{(i)} \in\left(Y_{1} \cup Y_{2}\right) \\
\text { or } P_{r e}^{(i)} \in\left(Y_{3} \cup Y_{4}\right)\end{array}$ & $\begin{array}{l}E S O C_{S} \text { is within the normal range. } \\
\text { The wind power is sufficient to satisfy } \\
\text { the local demands. The rest of the } \\
\text { wind power is within }\left(Y_{1} \cup Y_{2}\right) \\
\text { or }\left(Y_{3} \cup Y_{4}\right) \text {. }\end{array}$ & $\begin{array}{l}\text { The fuel cells suspend. Wind power is used for } \\
\text { water electrolysis which provide the hydrogen } \\
\text { for methanol production with } P_{\mathrm{H}_{2} \mathrm{O}}=\left|P_{r e}^{(i)}\right| \\
\text { or } P_{\mathrm{H}_{2} \mathrm{O}}=2 P_{m h g} \text {. The rest wind power is fed to } \\
\text { the grid. }\end{array}$ \\
\hline \multirow{3}{*}{$\begin{array}{l}i=3 \\
P_{r e}^{(i)}=P_{\text {wind }}\end{array}$} & $P_{r e}^{(i)}=0$ & $\begin{array}{l}E S O C_{S} \text { is below the lower limit. No } \\
\text { wind power provided. }\end{array}$ & $\begin{array}{l}\text { Both The fuel cell and water electrolysis process } \\
\text { suspend; No wind power is fed to the grid. }\end{array}$ \\
\hline & $P_{r e}^{(i)} \in\left(Y_{1} \cup Y_{2} \cup Y_{3}\right)$ & $\begin{array}{l}E S O C_{S} \text { is below the lower limit. } \\
\text { The wind power is within } \\
\left(Y_{1} \cup Y_{2} \cup Y_{3}\right) \text {. }\end{array}$ & $\begin{array}{l}\text { All wind power is used for water electrolysis } \\
P_{\mathrm{H}_{2} \mathrm{O}}=P_{r e}^{(i)}\end{array}$ \\
\hline & $P_{r e}^{(i)} \in Y_{4}$ & $\begin{array}{l}E S O C_{S} \text { is below the lower limit. } \\
\text { The wind power is within } Y_{4} \text {. }\end{array}$ & $\begin{array}{l}\text { The wind power used for water electrolysis } \\
P_{\mathrm{H}_{2} \mathrm{O}} \text { is equal to } 4 P_{m h g} \text {. The rest wind power is } \\
\text { fed to the grid. }\end{array}$ \\
\hline
\end{tabular}

\subsection{Electrical Power and ESOC Control}

Based on the control priority and the operating state of the system, a power distribution strategy is proposed. Its flow chart is shown in Figure 4. The power consumed by water electrolysis is obtained as follows:

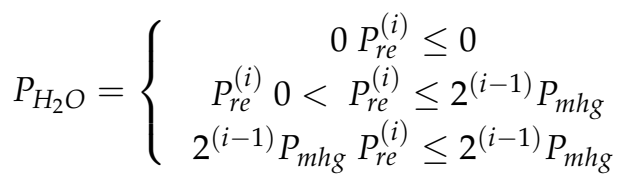

The fed-in wind power to the grid is given by:

$$
P_{S}=P_{\text {wind }}-P_{\mathrm{H}_{2} \mathrm{O}}
$$

All hydrogen is generated by water electrolysis and is consumed by either fuel cells or methanol production. Thus, the hydrogen distribution can be expressed by:

$$
\left\{\begin{array}{l}
n_{\mathrm{H}_{2} \mathrm{O}_{-} H}+n_{\Delta H}=n_{\text {mhg_H }}+n_{r H} \\
n_{\mathrm{H}_{2} \mathrm{O}_{-} \mathrm{O}}+n_{\Delta \mathrm{O}}=n_{\text {mhg_O }}+n_{r \mathrm{O}}
\end{array}\right.
$$

where $n_{\mathrm{H}_{2} \mathrm{O} \_}$and $n_{\mathrm{H}_{2} \mathrm{O} \_\mathrm{O}}$ are the amount of the hydrogen and oxygen produced by electrolysis of water respectively. $n_{\Delta H}$ and $n_{\Delta O}$ are the amount of the hydrogen and oxygen consumed in the tank respectively. $n_{r H}$ and $n_{r O}$ are the amount of hydrogen and oxygen that fed into the fuel cell respectively.

The hydrogen flow rate $\mathrm{N}_{\mathrm{H}_{2}}$ from the electrolysis of water power $P_{\mathrm{H}_{2} \mathrm{O}}$ is obtained:

$$
N_{\mathrm{H}_{2}}=\eta_{e} N_{e} \frac{I_{e}}{2 \mathrm{~F}}=\eta_{e} N_{e} \frac{P_{\mathrm{H}_{2} \mathrm{O}} / N_{e} U_{e}}{2 \mathrm{~F}}=\frac{\eta_{e} P_{\mathrm{H}_{2} \mathrm{O}}}{2 U_{e} F}
$$

where $\eta_{e}$ is the electrolysis efficiency of water electrolyser, which is generally between $60 \%$ and $80 \%$ [30]. $N_{e}$ is the number of electrolytic cells in series. F is the Faraday constant. Ie is the operating current of the cell which is given by dividing the consumption power $P_{\mathrm{H}_{2} \mathrm{O}}$ by the electrolyser voltage $U$ e. 


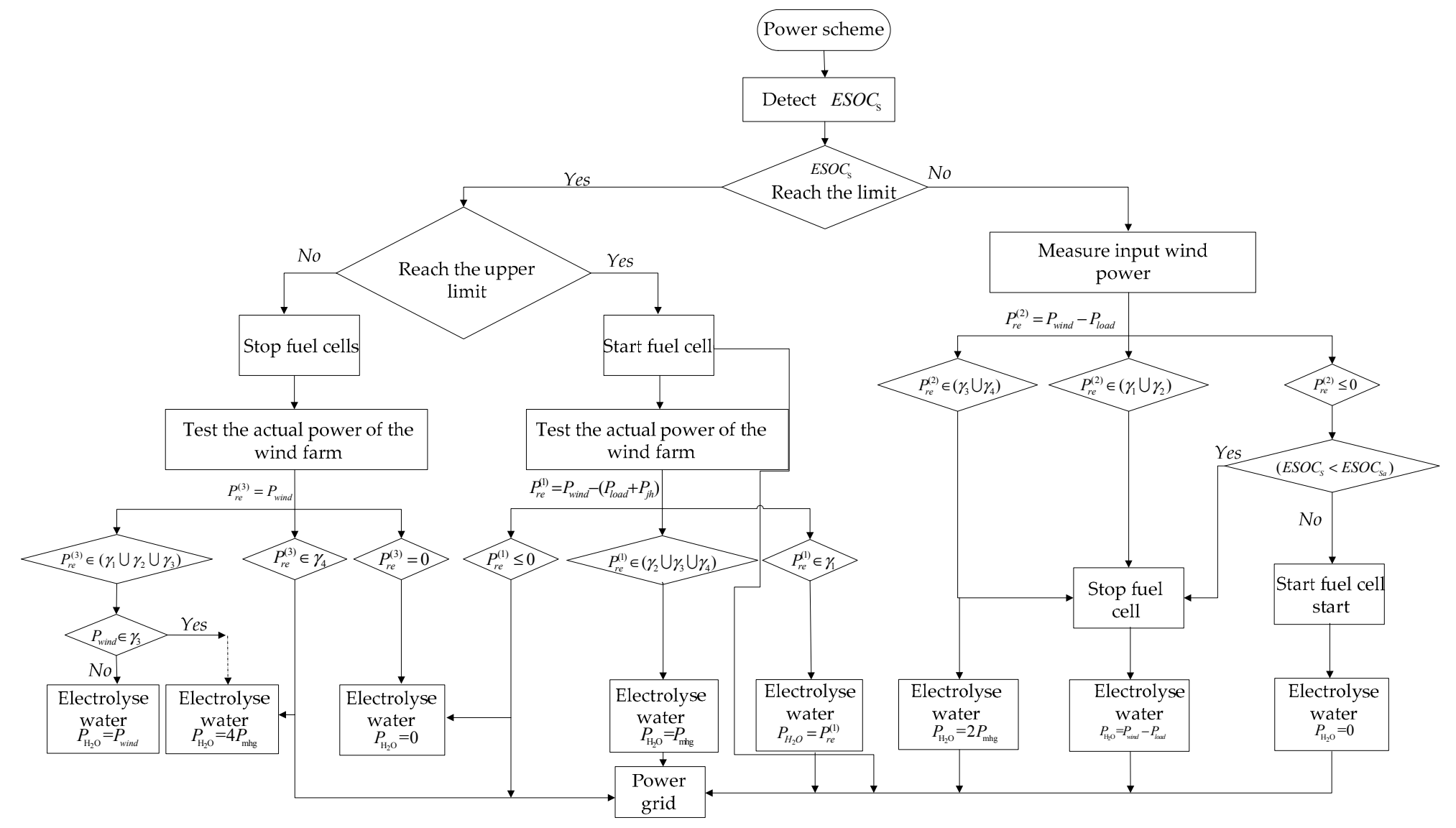

Figure 4. Control diagram of electric energy allocation. 
Thus:

$$
\left\{\begin{array}{l}
n_{\mathrm{H}_{2} \mathrm{O} \_\mathrm{H}}=\mathrm{N}_{\mathrm{H}_{2} \Delta t} \Delta t \\
n_{\mathrm{H}_{2} \mathrm{O} \_\mathrm{O}}=0.5 n_{\mathrm{H}_{2} \mathrm{O} \_\mathrm{H}}=0.5 \mathrm{~N}_{\mathrm{H}_{2}} \Delta t
\end{array}\right.
$$

Assuming the operation process is ideal, the amount of hydrogen and oxygen consumed in the coal chemical system during $\Delta t$ can be written as:

$$
\begin{gathered}
n_{\text {mh__ } H}=n_{\text {mhg_O }}=N_{\text {mhg }} \times \Delta t \\
N_{\text {mhg }}=207 \times 0.2 \times \frac{M_{W}}{3.6 V_{m}}
\end{gathered}
$$

where $M_{W}$ is the wind turbine output power (MW), and $V_{m}$ is the hydrogen molar volume $22.4 \mathrm{~L} / \mathrm{mol}$.

From Equation (8), $n_{r O}$ can be derived from $n_{\Delta H}$ and $n_{\Delta O}$, and vice versa. Thereby the state of the hydrogen storage system at the end of each cycle can be obtained. Therefore, the hydrogen distribution control is simplified to study the operation state of the fuel cells. The cases for the fuel cells discharging can be summarised as the follows:

(1) If $P_{r e}^{(1)} \geq 0$, reduce $E S O C_{S}$ by consuming more hydrogen and oxygen for electricity generation, Let flag1 $=1$. Logical order is to derive $n_{r H}, n_{r O}\left(P_{f c}\right)$ from $n_{\Delta H}, n_{\Delta O}$.

At this moment, the amount of hydrogen and oxygen can reach the upper limits of the tank pressure $n_{\Delta H}, n_{\Delta O}$ :

$$
\left\{\begin{array}{c}
n_{\Delta H}^{\prime}=p_{H c a p} \mathrm{~V}_{H c a p}\left(E S O C_{H}-E S O C_{H_{-} \max }\right) / \mathrm{RT}_{H} \\
n_{\Delta O}^{\prime}=p_{\text {Ocap }} \mathrm{V}_{\text {Ocap }}\left(E S O C_{O}-E S O C_{O_{-} \max }\right) / \mathrm{RT}_{O}
\end{array}\right.
$$

\begin{tabular}{|c|c|c|c|}
\hline$n_{\Delta \mathrm{O}}^{\prime} \quad n_{\Delta \mathrm{H}}^{\prime}$ & $<0$ & $=0$ & $>0$ \\
\hline$<0$ & - & - & select $n_{\Delta \mathrm{H}}=n_{\Delta \mathrm{H}}^{\prime}$ \\
\hline$=0$ & - & - & select $n_{\Delta \mathrm{H}}=n_{\Delta \mathrm{H}}^{\prime}$ \\
\hline$>0$ & Select $n_{\Delta O}=n_{\Delta O}^{\prime}$ & Select $n_{\Delta O}=n_{\Delta O}^{\prime}$ & $\begin{array}{ll}n_{\Delta H}=n_{\Delta H}^{\prime} & \text { if } n_{\Delta H}^{\prime} \geq 2.3 n_{\Delta O}^{\prime} \\
n_{\Delta O}=n_{\Delta O}^{\prime} & \text { if } n_{\Delta H}<n_{\Delta O}^{\prime}\end{array}$ \\
\hline
\end{tabular}

The calculations of the parameters $n_{\Delta H}, n_{\Delta O}$ are shown in Table 3 .

Table 3. Parameter selection for the calculation.

The molar flow rate of the hydrogen and the oxygen in the fuel cell is:

$$
1<\gamma_{\mathrm{H}-\mathrm{O}}=n_{r \mathrm{H}} \Delta t / n_{r \mathrm{O}} \Delta t<1.25
$$

i. The actual stock of the hydrogen is calculated by:

$$
\left\{\begin{array}{l}
n_{r H}=n_{H_{2} O_{-} H}+n_{\Delta H}-n_{m h g_{-} H} \\
n_{r O}=\frac{n_{r H}}{\gamma_{H-O}}
\end{array}\right.
$$

ii. The actual stock of the oxygen is calculated by:

$$
\left\{\begin{array}{l}
n_{r O}=n_{H_{2} O_{O}}+n_{\Delta O}-n_{m h g_{O}} \\
n_{r H}=\gamma_{H-O} n_{r O}
\end{array}\right.
$$


The partial pressures of hydrogen and oxygen $p_{f c_{-} H}, p_{f_{c_{-} o}}$ are obtained:

$$
\left\{\begin{array}{l}
p_{f c_{-} H}=\left(\frac{n_{r H}}{N \Delta t}-\frac{d p_{f c_{-} H}}{d t} \cdot \frac{10^{5} \mathrm{~V}_{a}}{\mathrm{RT}}-\frac{N I_{f c}}{2 \mathrm{~F}}\right) / 10^{5} K_{H_{2}} \\
p_{f c_{-} O}=\left(\frac{n_{r O} O}{N \Delta t}-\frac{d p_{f c_{-} O}}{d t} \cdot \frac{10^{5} \mathrm{~V}_{c a}}{\mathrm{RT}}-\frac{N I_{f c}}{4 \mathrm{~F}}\right) / 10^{5} K_{O_{2}}
\end{array}\right.
$$

where $N$ is the number of the fuel cell units, $V_{a}$ and $V_{c a}$ is anode and cathode volumes per unit hydrogen fuel cell respectively, $\mathrm{T}$ is the operating temperature of the fuel cell, $I_{f_{c}}$ is the current of the fuel cell, $K_{\mathrm{H}_{2}}$ and $\mathrm{K}_{\mathrm{O}_{2}}$ are the molar constant of hydrogen (anode) and oxygen (cathode) respectively.

Based on a fuel cell model, the power of the fuel cell $P_{f_{c}}\left(P_{f_{c}} \geq 0\right)$ can be obtained:

$$
P_{f c}=\left\{\begin{array}{c}
P_{f c_{-} \min }, \eta_{f}\left(U_{f c} \cdot I_{f c}\right)<P_{f c_{-} \min } \\
\eta_{f}\left(U_{f c} \cdot I_{f c}\right), P_{f c_{-} \min } \leq \eta_{f}\left(U_{f c} \cdot I_{f c}\right) \leq P_{f c_{-} \max } \\
P_{f c_{-} \max }, \eta_{f}\left(U_{f c} \cdot I_{f c}\right)>P_{f c_{-} \max }
\end{array}\right.
$$

where $U_{f c}$ is the output voltage of the fuel cell, $\eta_{f}$ is the power generation efficiency of the fuel cell, $P_{f c_{-} \max }$ and $P_{f c_{-} \min }$ are the upper and the lower limits of the fuel cell stack, respectively. Based on double electric layer phenomenon, the output voltage of the hydrogen fuel cell is calculated as follows [31-33]:

$$
U_{f c}=N \cdot U_{\text {cell }}=N \cdot\left(E_{\text {nernst }}-U_{\text {ohmic }}-U_{c}\right)
$$

where $U_{\text {cell }}$ is the output voltage of a single fuel cell, $E_{\text {nernst }}$ is the thermodynamic potential, $U_{\text {ohmic }}$ is the ohmic polarization overvoltage, and $U_{c}$ is the equivalent voltage.

The thermodynamic potential can be calculated by Equation (21):

$$
E_{\text {nernst }}=1.229-8.5 \times 10^{-4}(\mathrm{~T}-298.15)+4.3085 \times 10^{-5} \mathrm{~T} \times\left(\ln p_{f_{\mathcal{C}_{-} H}}+0.5 \ln p_{f_{\mathcal{C}_{-} O}}\right)
$$

The ohmic polarization overvoltage is obtained by:

$$
U_{o h m i c}=I_{f c}\left(Z_{m}+Z_{c}\right)=I_{f c}\left(\frac{181.6 l\left[1+0.03 \frac{I_{f c}}{A}+0.062\left(\frac{T}{303}\right)^{2}\left(\frac{I_{f c}}{A}\right)^{2.5}\right]}{A\left(\varphi-0.634-3 \frac{I_{f c}}{A}\right) \times \exp \left[4.18\left(\frac{T-303}{T}\right)\right]}+Z_{c}\right)
$$

where $Z_{m}$ is the equivalent membrane impedance; $Z_{c}$ is the impedance which represents the proton through the exchange membrane; $\rho_{M}$ is the resistivity; $l$ is the film thickness; $A$ is the activation area of proton exchange membrane; and $\varphi$ is the proton exchange membrane moisture content. The cell equivalent voltage can be given by:

$$
\begin{aligned}
U_{c}= & \left\{-B \times \ln \left(1-\frac{J}{I_{\max }}\right)-\left[\varepsilon_{1}+\varepsilon_{2} \mathrm{~T}+\varepsilon_{3} \mathrm{~T} \ln \left(\frac{p_{f_{c}-O} \times 10^{2}}{5.08 \times 10^{6} \exp \left(-\frac{498}{\mathrm{~T}}\right)}\right)\right.\right. \\
& \left.\left.+\varepsilon_{4} \mathrm{~T} \ln \left(I_{f_{c}}\right)\right]\right\}\left(1-\frac{C}{I_{f c}} \times \frac{d U_{c}}{d t}\right)
\end{aligned}
$$

where $B$ is the equation coefficient; $J$ is the active current density of the cell; $J_{\max }$ is the maximum current density; $C$ is the equivalent capacitance; and $\varepsilon_{1}, \varepsilon_{2}, \varepsilon_{3}, \varepsilon_{4}$, are the empirical parameters of fuel cell.

(2) If $\left(P_{r e}^{(2)}<0\right) \&\left(E S O C_{S} \geq E S O C_{S a}\right)$ or $\left(P_{r e}^{(1)}<0\right), E S O C_{S}$ level is operated within ideal range but the wind power cannot meet the demand. The hydrogen fuel cell discharges to assist wind power with flag $1=1 . n_{r H}$ and $n_{r O}$ can be obtained by the $P_{f c}$ and then $n_{\Delta H}$ and $n_{\Delta O}$ can be derived.

$$
P_{f \mathcal{C}}=\left\{\begin{array}{l}
P_{f c_{-} \min },\left|P_{r e}^{i}\right|<P_{f c_{-} \min } \\
\left|P_{r e}^{i}\right|, P_{f c_{-} \min } \leq\left|P_{r e}^{i}\right| \leq P_{f c_{-} \max } \quad i=1,2 \\
P_{f c_{-} \max },\left|P_{r e}^{i}\right|>P_{f_{c} \text { max }}
\end{array}\right.
$$


The above equation can be simplified as:

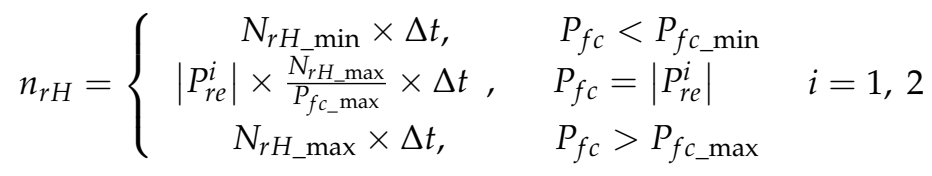

where $N_{r H \_m i n}$ is the flow rate of the hydrogen when the fuel cell operates at minimum power output:

$$
n_{r O}=n_{r H} / 1.2
$$

(3) If $\left(P_{r e}^{(2)}<0\right) \&\left(E S O C_{S}<E S O C_{S a}\right)$, or $P_{r e}^{(2)} \geq 0$ or $P_{r e}^{(3)} \geq 0$, the hydrogen fuel cell suspends with flag1 $=0$.

Let $P_{f c}=0, n_{r H}=n_{r O}=0$, then $n_{\Delta H}=n_{m h g_{-} H}-n_{H_{2} O_{-} H}, n_{\Delta O}=n_{m h g_{-} O}-n_{H_{2} O_{-} O}$.

According to the above control rules, the HESS pressure $p_{\text {Hre }}$ is obtained:

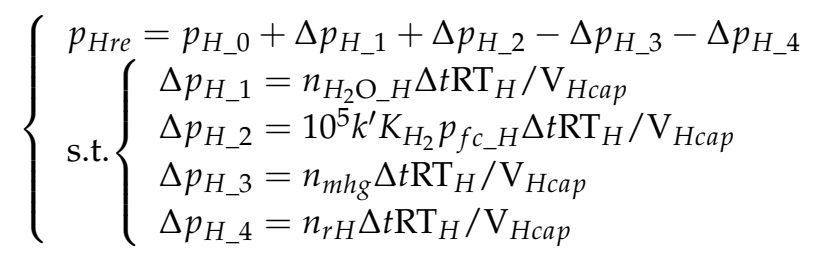

where $p_{H_{-} 0}$ is the initial pressure of the hydrogen tank; $\Delta p_{H_{-} 1}$ is the pressure increment of the hydrogen caused by water electrolysis; $\Delta p_{H_{-} 2}$ is the pressure increment of the hydrogen caused by incomplete consumption from the fuel cells. $\Delta p_{H_{-} 3}$ is the pressure decrement of the hydrogen caused by methanol production. $\Delta p_{H_{-} 4}$ is the pressure decrement of the hydrogen caused by the fuel cell discharging. $k^{\prime}$ is the hydrogen recovery rate.

The pressure of the oxygen tank $p_{\text {Ore }}$ is calculated by:

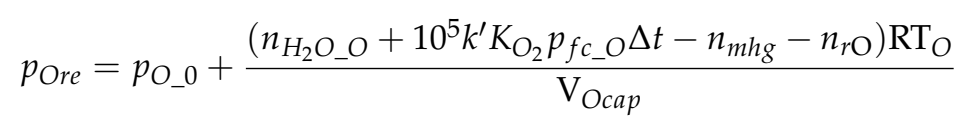

where $p_{O_{-} 0}$ is the initial pressure of the oxygen tank.

\subsection{Overall Control Scheme}

This study is focused on the optimal operation of the hybrid system. When the cluster power is required by the cluster control center, the power from the hybrid system is sent to the grid after the local demand is satisfied. In order to communicate with the cluster control center, a specific indicator "flag2" is used.

By changing flag2, the operation states and the request of the local hybrid system are recorded. The specific actions are as follows:

If $P_{s}+P_{f c}<P_{\text {load }}+P_{j h}$, flag2 $=-1$, the local system does not satisfy with the grid plan and the local system requests the cluster control center to provide power assistance;

If $P_{\mathrm{s}}+P_{f c}=P_{\text {load }}+P_{j h}$, flag2 $=0$, the local system operates in an ideal state and the established target is realised;

If $P_{\mathrm{s}}+P_{f_{c}}>P_{\text {load }}+P_{j h}$, flag2 $=1$, the local system requests assistance from cluster control center and the more power from the local system is sent to the grid.

In order to prevent the amounts of hydrogen and oxygen from reaching their tank limits, an additional control action is developed, as shown in Figure 5. 


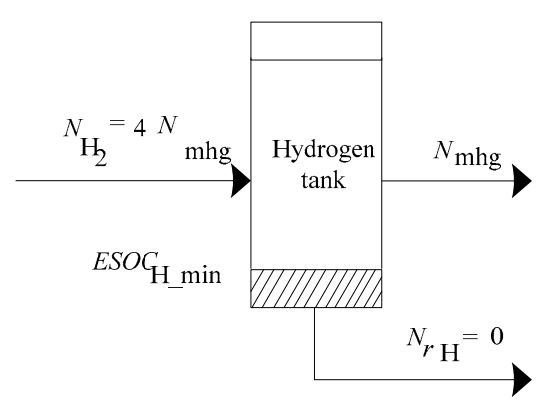

(a) Producing hydrogen with maximum flow rate and consuming hydrogenwith minimum flow rate

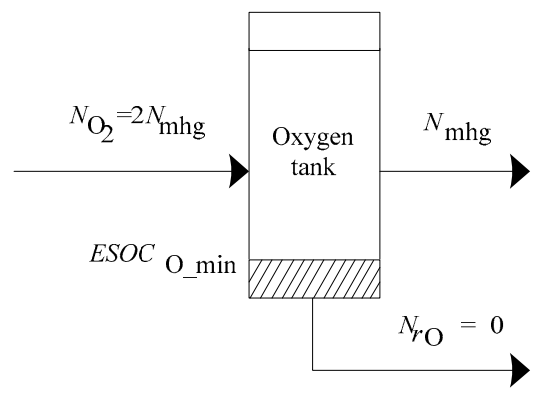

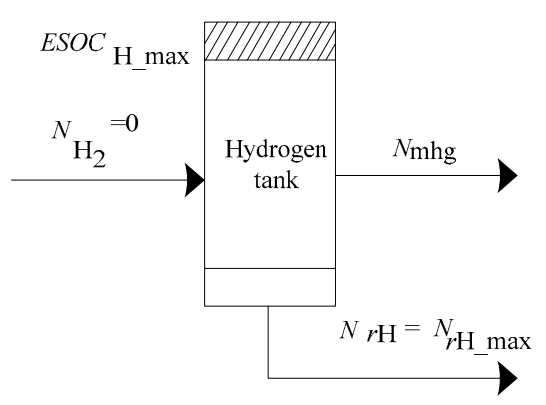

(b) Producing hydrogen with minimum flow rate and consuming hydrogen with maximum flow rate

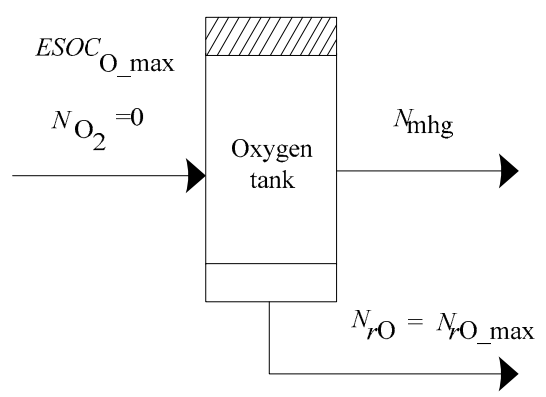

(c) Producing oxygen with maximum flow rate and consuming (d) Producing oxygen with minimum flow rate and consuming oxygen with minimum flow rate oxygen with maximum flow rate

Figure 5. The extreme cases of hydrogen energy storage system operation.

i. As shown in Figure $5 \mathrm{a}, \mathrm{c}$, when $E S O C_{H}$ or $E S O C_{O}$ is lower than $E S O C_{H_{-} \min }$ or $E S O C_{O_{-} \min }$ the hybrid system produces the hydrogen/oxygen in maximum and consumes the hydrogen/ oxygen in minimum. $\Delta t_{a}$ should select the smaller one between $\Delta t_{a H}$ and $\Delta t_{a \mathrm{O}}$ :

$$
\Delta t_{a}=\left\{\begin{array}{l}
\min \left(\Delta t_{a H}, \Delta t_{a O}\right) \\
\text { s.t. }\left\{\begin{array}{l}
\Delta t_{a H}=\frac{\left(E S O C_{H_{-} \max }-E S O C_{H_{\text {_min }}}\right) p_{\text {Hcap }} \mathrm{V}_{\text {Hcap }}}{\left(4 N_{\text {mhg }}-N_{\text {mhg }}\right) \mathrm{RT}_{H}} \\
\Delta t_{a O}=\frac{\left(E S O C_{\left.O_{-\max }-E S O C_{O-\min }\right) p_{\text {Ocap }} \mathrm{V}_{\text {Ocap }}}\right.}{\left(2 N_{\text {mhg }}-N_{\text {mhg }}\right) \mathrm{RT}_{O}}
\end{array}\right.
\end{array}\right.
$$

ii. As shown in Figure $5 \mathrm{~b}, \mathrm{~d}$, when $E S O C_{H}$ or $E S O C_{O}$ is over than $E S O C_{H_{-} \max }$ or $E S O C_{O_{-} \max }$, the hybrid system produces the hydrogen/oxygen in minimum and consumes hydrogen/oxygen in maximum. $\Delta t_{b}$ should select the smaller one between $\Delta t_{b H}$ and $\Delta t_{b O}$ :

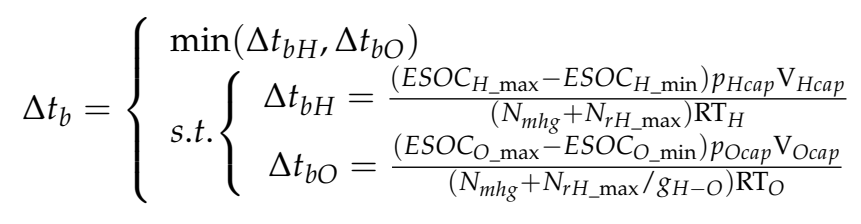

Therefore, the time interval $\Delta t$ is controlled to be:

$$
\Delta t<\min \left(\Delta t_{a}, \Delta t_{b}\right)
$$

\section{Simulation Results}

The simulation of a local hybrid system with $10 \mathrm{MW}$ wind power has been carried out by using MATLAB/Simulink. The key parameters of the system are shown in Table 4. 
Table 4. Key parameters of the hybrid system.

\begin{tabular}{|c|c|c|c|}
\hline Parameter & Value & Parameter & Value \\
\hline$U_{e}$ & $2 \mathrm{~V}$ & $A$ & $50 \mathrm{~cm}^{2}$ \\
\hline$\eta_{e}$ & $80 \%$ & $\varphi$ & 14 \\
\hline$R$ & $8.3145 \mathrm{~J} / \mathrm{mol} \cdot \mathrm{K}$ & C & $3 \mathrm{~F}$ \\
\hline$V_{\text {Hcap }}$ & $60 \mathrm{~m}^{3}$ & $\varepsilon_{1}$ & -0.9514 \\
\hline$V_{\text {Ocap }}$ & $60 \mathrm{~m}^{3}$ & $\varepsilon_{2}$ & $3.12 \times 10^{-3}$ \\
\hline$p_{\text {Hcap }}$ & $5 \times 10^{6} \mathrm{~Pa}$ & $\varepsilon_{3}$ & $7.4 \times 10^{-5}$ \\
\hline$p_{\text {Ocap }}$ & $5 \times 10^{6} \mathrm{~Pa}$ & $\varepsilon_{4}$ & $-1.87 \times 10^{-4}$ \\
\hline$p_{H \_0}$ & $4.499 \times 10^{6} \mathrm{~Pa}$ & $B$ & 0.016 \\
\hline$p_{O \_} 0$ & $4.499 \times 10^{6} \mathrm{~Pa}$ & $J_{\max }$ & $1.2 \mathrm{~A} / \mathrm{cm}^{2}$ \\
\hline$T_{H}$ & $298 \mathrm{~K}$ & $\eta_{f}$ & $90 \%$ \\
\hline$T_{O}$ & $298 \mathrm{~K}$ & $I_{f \mathcal{C}}$ & $25 \mathrm{~A}$ \\
\hline$K_{H_{2}}$ & $6.781 \times 10^{-2} \mathrm{~mol} / \mathrm{s} \cdot \mathrm{atm}$ & $\mathrm{V}_{a}$ & $0.005 \mathrm{~m}^{3}$ \\
\hline $\mathrm{K}_{\mathrm{O}_{2}}$ & $6.781 \times 10^{-2} \mathrm{~mol} / \mathrm{s} \cdot \mathrm{atm}$ & $\mathrm{V}_{c a}$ & $0.01 \mathrm{~m}^{3}$ \\
\hline$k^{\prime}$ & 0.9 & $P_{f_{C_{-}} \max }$ & $0.2 \mathrm{MW}$ \\
\hline$N$ & 400 & $P_{f C_{-} \min }$ & $2 \times 10^{-4} \mathrm{MW}$ \\
\hline$T$ & $350 \mathrm{~K}$ & $N_{r H \text { max }}$ & $27,140 \mathrm{~mol} / \mathrm{s}$ \\
\hline$l$ & $5.1 \times 10^{-3} \mathrm{~cm}$ & $N_{r H \_ \text {min }}$ & $1.357 \mathrm{~mol} / \mathrm{s}$ \\
\hline
\end{tabular}

In the simulation, $E S O C_{S a}$ is set $0.31 . P_{m h g}$ and $N_{m h g}$ are set $2.48 \mathrm{MW}$ and $5.134 \mathrm{~mol} / \mathrm{s}$ respectively. According to Equations (28) and (29), $\Delta t$ is less than 3.75. Therefore let $\Delta t=0.5 \mathrm{~s}$. The input and the output power curves are shown in Figures 6 and 7, respectively. The wind power data are from a real $50 \mathrm{MW}$ wind over a 15-h duration. In order to validate the proposed models, the data are scaled down to fit the $10 \mathrm{MW}$ wind turbine model and the time duration is reduced from $15 \mathrm{~min}$ to $1 \mathrm{~s}$. ESOC $S$ exceed the upper limit (0.9) at $11 \mathrm{~s}$ as shown in Figure 7, the fuel cell discharges and the $E S O C_{S}$ reduces. After a control period, $E S O C_{S}$ restores normal. From $26 \mathrm{~s}$ to $27.5 \mathrm{~s}$ and from $31.5 \mathrm{~s}$ to $34.5 \mathrm{~s}$, the $E S O C_{S}$ is in the normal range and the storage state is normal. The fuel cells discharge to assist wind power integration, and ensure the output power of the hybrid system to meet the tied-grid demand.

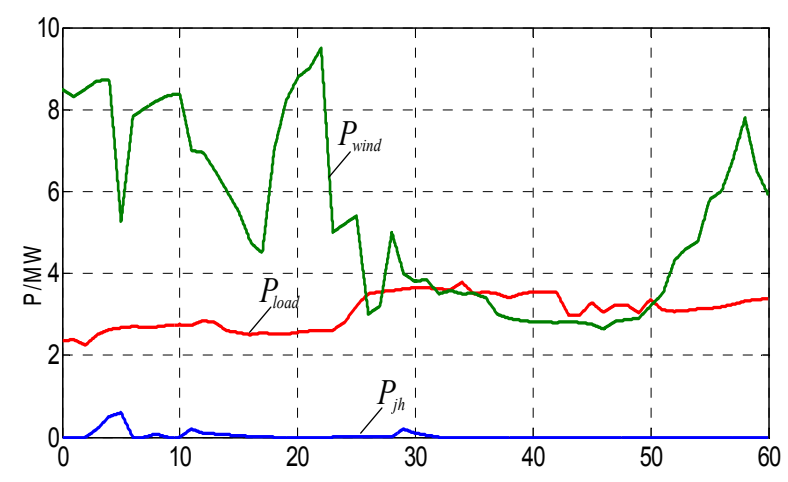

Figure 6. Output power, load and scheduled power curves. 


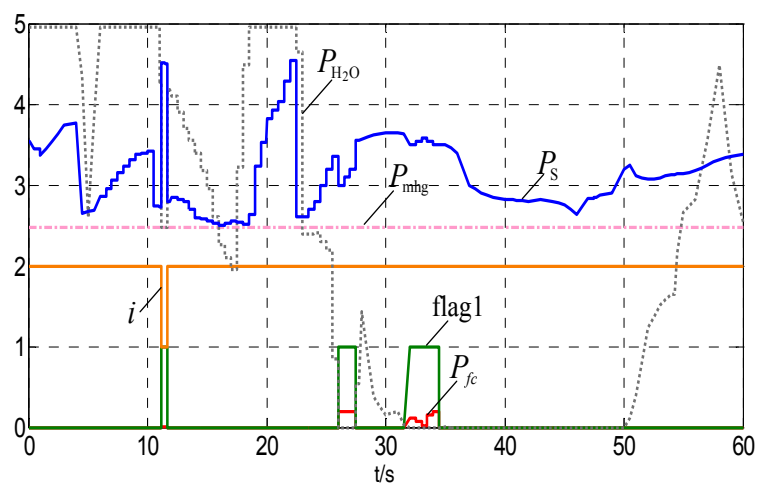

Figure 7. The wind power and the fuel cell power.

Therefore, actual tied-grid power and tied-grid demand curves of the hybrid system are shown as Figure 8.

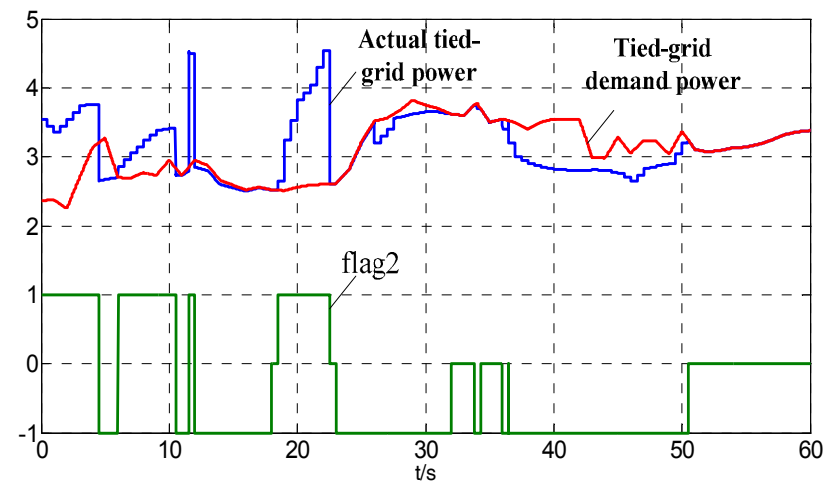

Figure 8. Tied-grid power and overall operation status.

It can be seen from Figure 8 that when actual tied-grid power of the hybrid system does not meet the tied-grid demand, that is $P_{s}+P_{f c}<P_{l o a d}+P_{j h}$, flag2 is set -1 and the hybrid system requests the cluster center for assistance. Otherwise, flag 2 is set 1 , the local hybrid system power is excess. If the system power equates the tied-grid demand, the flag2 is set 0 . The control objective is achieved. In the above process, the states of the hydrogen/oxygen tanks and HESS are shown in Figures 8-11.

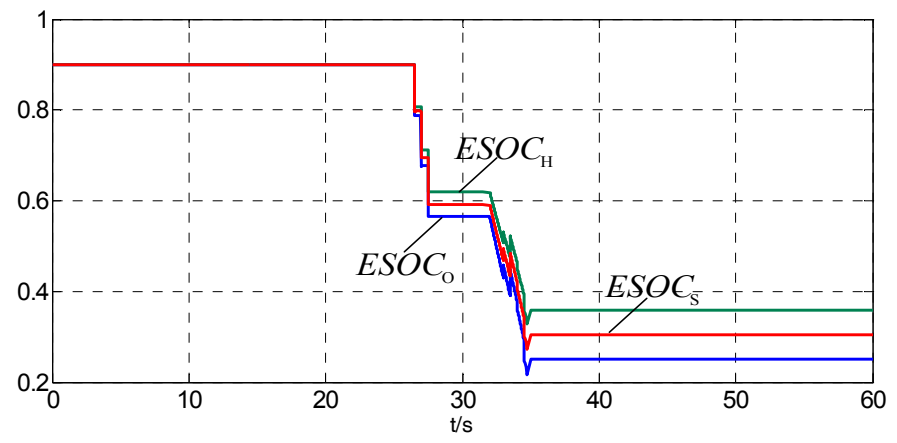

Figure 9. The ESOC of the hydrogen tank, oxygen tank and HESS. 


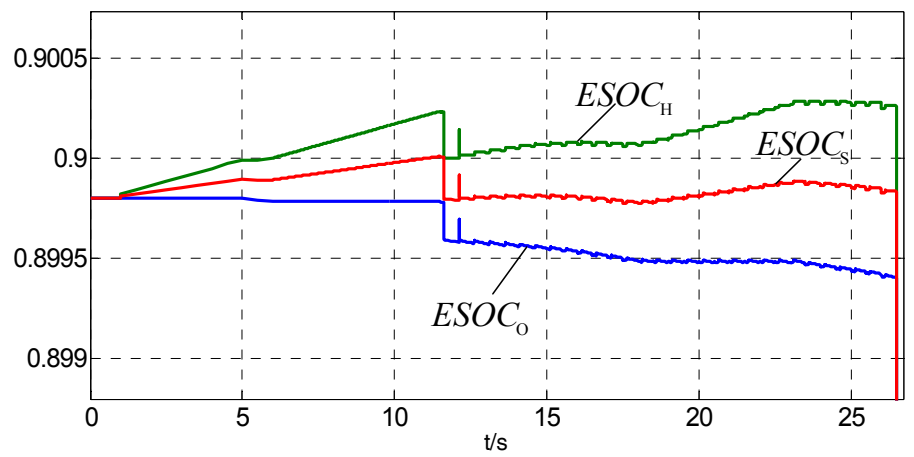

Figure 10. The ESOC from $0 \mathrm{~s}$ to $26 \mathrm{~s}$.

It can be seen from Figures 9 and 10 that the $E S O C_{S}$ is in the normal range at the beginning. $P_{\mathrm{H}_{2} \mathrm{O}}$ equates $2 P_{m h g}$ from $0 \mathrm{~s}$ to $4 \mathrm{~s}$ and from $6 \mathrm{~s}$ to $11 \mathrm{~s}$. The $E S O C_{H}$ and the $E S O C_{S}$ rise slowly and the $E S O C_{O}$ remains unchanged. From $4 \mathrm{~s}$ to $6 \mathrm{~s}$, from $11.5 \mathrm{~s}$ to $16 \mathrm{~s}$ and from $17.5 \mathrm{~s}$ to $23 \mathrm{~s}, P_{m h g}<P_{\mathrm{H}_{2} \mathrm{O}}<2 P_{m h g}$. The $E S O C_{H}$ and the $E S O C_{S}$ rise slowly and the ESOC $O$ decreases slowly. At $11 \mathrm{~s}, E S O C_{S}$ exceeds the upper limit, and the control priority changes. The fuel cells start, and $E S O C_{H}, E S O C_{O}$ and $E S O C_{S}$ drop rapidly. The $E S O C_{S}$ restores to the normal range. From $23 \mathrm{~s}$ to $26 \mathrm{~s}, P_{\mathrm{H}_{2} \mathrm{O}}<P_{m h g}$. The $E S O C_{H}, E S O C_{O}$ and $E S O C_{S}$ decrease slowly.

It can be seen from Figure 7 that $P_{\mathrm{H}_{2} \mathrm{O}}$ drops rapidly since $26 \mathrm{~s}$. From $26 \mathrm{~s}$ to $36 \mathrm{~s}, P_{\mathrm{H}_{2} \mathrm{O}}$ is less than $P_{m h g}$ and even reduces to zero at $31 \mathrm{~s}$. From $26 \mathrm{~s}$ to $27.5 \mathrm{~s}$ and from $31 \mathrm{~s}$ to $34.5 \mathrm{~s}$, the fuel cells discharge, and the $E S O C_{H}, E S O C_{O}$ and $E S O C_{S}$ decrease rapidly as can be seen in Figure 11. From $27.5 \mathrm{~s}$ to $31.5 \mathrm{~s}$, the fuel cells suspend and the hydrogen produced by water electrolysis is less than the hydrogen used for coal chemical process. The $E S O C_{H}, E S O C_{O}$ and $E S O C_{S}$ decrease slowly. At $34.5 \mathrm{~s}, E S O C_{S}<E S O C_{S a}$ and the fuel cells suspend. The downward trend of the $E S O C_{H}, E S O C_{O}$ and $E S O C_{S}$ has been curbed.

It can be seen from Figures 7 and 12 that $E S O C_{S_{-} \text {min }}<E S O C_{S}<E S O C_{S a}$ between $35 \mathrm{~s}$ and $60 \mathrm{~s}$ while the fuel cells suspend. From $35 \mathrm{~s}$ to $50 \mathrm{~s}, P_{\mathrm{H}_{2} \mathrm{O}}=0$ and the hydrogen/oxygen for the coal chemical process are provided by the tanks. $E S O C_{S}$ decreases slowly. From 50 s onwards, $P_{\mathrm{H}_{2} \mathrm{O}}$ rises slowly. However, it does not reach $2 P_{m h g}$ until $60 \mathrm{~s}$. Therefore, $E S O C_{S}$ is seen decreasing in this period.

In Figure 13, when the hydrogen for the methanol production is zero, ESOC ${ }_{S}$ decreases 0.0004 within $15 \mathrm{~s}$. It is at $1 \mathrm{~s}$ that $E S O C_{S}$ decreases from $E S O C s_{a}$ to $E S O C_{S_{-} \text {min }}$ under unchanged condition. Therefore, let:

$$
p_{H \_0}=1268049.26 \mathrm{P}_{a}
$$

and:

$$
p_{O \_0}=732049.26 \mathrm{P}_{a}
$$

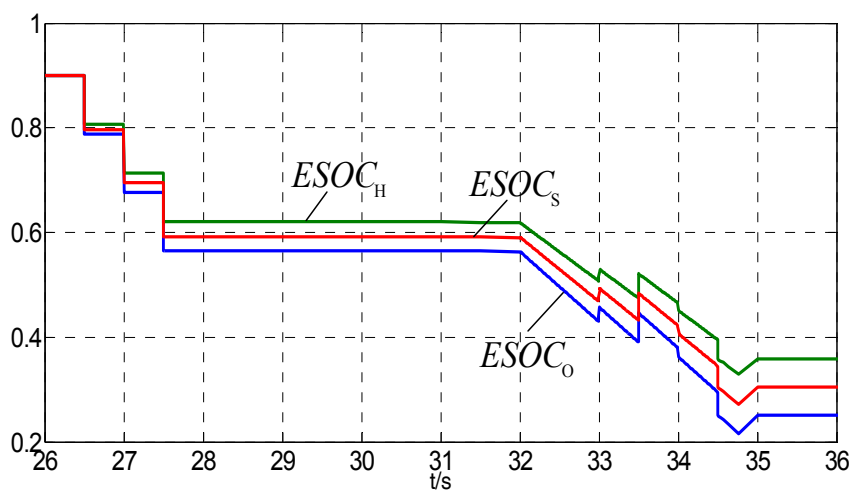

Figure 11. The ESOC from $26 \mathrm{~s}$ to $35 \mathrm{~s}$. 


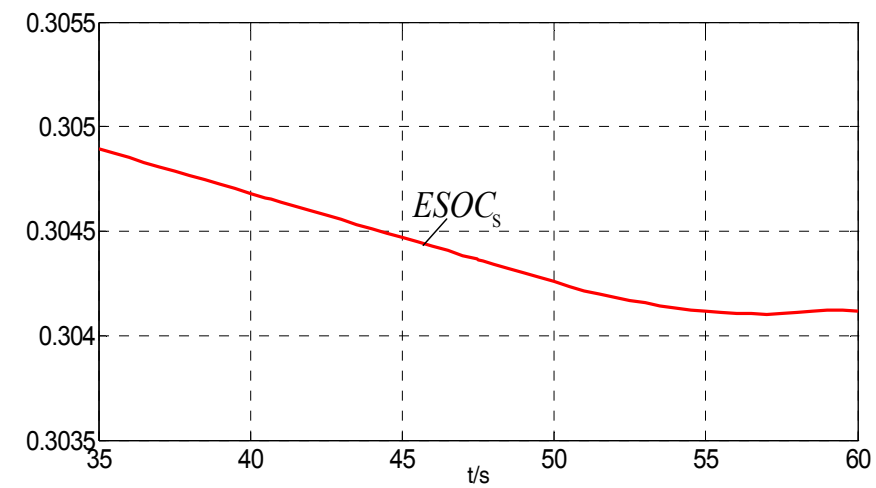

Figure 12. The ESOC from $35 \mathrm{~s}$ to $60 \mathrm{~s}$.

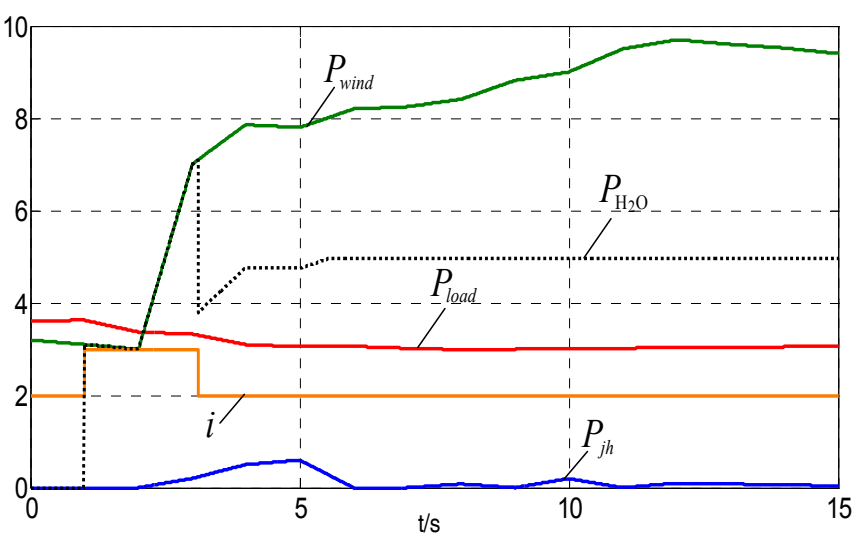

Figure 13. The power and the flag bit curve beyond lower limit.

The simulations when $E S O C_{S}$ below the low limit is carried out based on this model. The hydrogen tank and the ESOC of the HESS are shown in Figures 14 and 15. In Figures 14 and 15, the ESOC $S$ reach the lower limit and the control priority changes. The wind power is used for the water electrolysis at $1 \mathrm{~s}$. The $E S O C_{S}$ recovers to the normal range at $3 \mathrm{~s}$. After that, the power for the water electrolysis increases and maintains $2 P_{m h g}$ until $5.5 \mathrm{~s}$. The $E S O C_{H}, E S O C_{O}$ and $E S O C_{S}$ increase slowly.

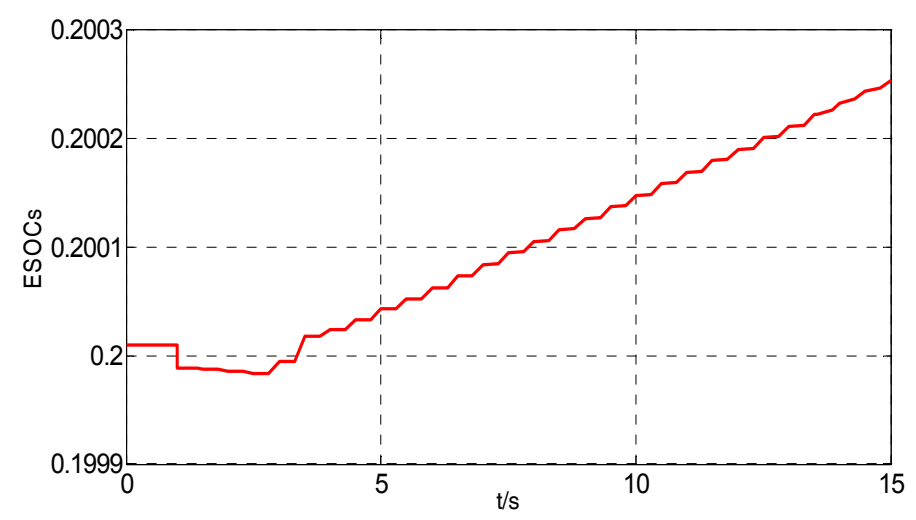

Figure 14. The curve of the ESOCs below the low limit. 


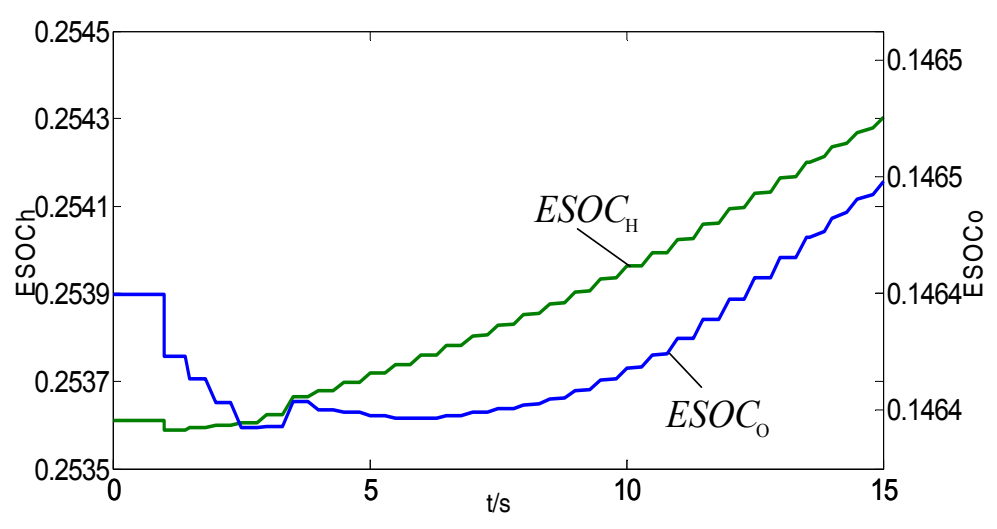

Figure 15. The curve of the $E S O C_{H}$ and $E S O C_{O}$ below the low limit.

\section{Conclusions}

This paper has presented a new hybrid system involving wind turbines, hydrogen energy storage, water electrolyser, and fuel cells. The novelty lies in the coordinated control scheme to maximize the utilisation of wind power with a constant methanol output whilst still reducing $\mathrm{CO}_{2}$ emissions. All the symbols used in the paper can refer to Table A1 in Appendix A. The main contributions of the study can be concluded as follows:

(1) This work takes advantage of wind power for electricity generation and for energy storage. In addition, coal-based energy systems for methanol production in a cleaner manner. This is critically important for China as well as many coal-dependent economies.

(2) It integrates some interdisciplinary techniques into a multi-functional dynamic system to effectively manage various energy sources to enhance stable power supply stability, increase energy efficiency in utilization, and reduce $\mathrm{CO}_{2}$ emissions.

(3) It proposes a concept prototype and then implements the structured system in a simulation environment, which significantly reduces the real test cost.

(4) The simulation results have confirmed the technical feasibility of the proposed system. It paves the way for next stage progression in small scale real tests and future commercialization of the technology.

(5) Because of the optimal design and control of the hybrid system, energy efficiency and cost efficiency will be improved. This has a significant economic implications. Moreover, the reduction in $\mathrm{CO}_{2}$ emissions will have an additional benefit from Carbon Trading Scheme in China.

As this is just a theoretical study in pioneering stage in China, there are several pertinent aspects need to be fully investigated before real system implementation and applications. These are:

(1) Development of a full-scale simulation with hardware-in-loop real-time simulator for feasibility investigation.

(2) Development of a full scale demonstration experimental setup of the system.

(3) Conduction economic analysis, costs and gains, energy trading and carbon trading.

(4) Carrying out a study on other social, environmental, legal impacts to minimize the uptake of the proposed technology.

Acknowledgments: This research is supported by National Natural Science Foundation of China (NSFC 51367018, 51321005) and Xinjiang Science Foundation for Distinguished Young Scholars (2014711005).

Author Contributions: In this article, T. Yuan and Q. Duan conceived and designed the system; J. Hu and X. Yuan performed the experiments; Q. Zhu built the simulation models; X. Chen and W. Cao analysed data and wrote the paper.

Conflicts of Interest: The authors declare no conflict of interest. 


\section{Appendix A}

Table A1. Symbols.

\begin{tabular}{|c|c|c|}
\hline 1 & $A$ & Active area of the membrane \\
\hline 2 & $B$ & Equation coefficient \\
\hline 3 & C & Equivalent capacitor of fuel cell \\
\hline 4 & $E_{\text {nernst }}$ & Thermodynamic potential \\
\hline 5 & ESOC & Equivalent state of charge \\
\hline 6 & $E S O C_{H}$ & Equivalent state of charge of the hydrogen tank \\
\hline 7 & $\mathrm{ESOC}_{S}$ & Equivalent state of charge of the HESS \\
\hline 8 & $\mathrm{ESOC}_{S_{a}}$ & Threshold of ESOC \\
\hline 9 & $\operatorname{ESOC}_{O}^{a}$ & Equivalent state of charge of the oxygen tank \\
\hline 10 & $E S O C_{X \_\max }$ & The upper limit of the ESOC \\
\hline 11 & $E S O C_{X \_ \text {min }}$ & The low limit of the ESOC \\
\hline 12 & $F$ & Faraday constant \\
\hline 13 & $I_{e}$ & Current in water electrolyser \\
\hline 14 & $I_{f_{c}}$ & Discharge current of fuel cell \\
\hline 15 & $J$ & ampere density in fuel cell \\
\hline 16 & $J_{\max }$ & Maximum ampere density in fuel cell \\
\hline 17 & $k^{\prime}$ & Fuel recovery rate \\
\hline 18 & $k_{\mathrm{H}_{2}}$ & Hydrogen constant \\
\hline 19 & $K_{\mathrm{O}_{2}}$ & Oxygen constant \\
\hline 20 & $l$ & Thickness of the membrane \\
\hline 21 & $M_{W}$ & Nominal capacity of the wind farm \\
\hline 22 & $n_{\mathrm{H}_{2} \mathrm{O} \_\mathrm{H}}$ & Hydrogen production amount by water electrolysis in $\Delta t$ \\
\hline 23 & $n_{\mathrm{H}_{2} \mathrm{O} \_\mathrm{O}}$ & Oxygen production amount by water electrolysis in $\Delta t$ \\
\hline 24 & $n_{m h g \_H}$ & Hydrogen consumption by methanol production in $\Delta t$ \\
\hline 25 & $n_{m h g \_O}$ & Oxygen consumption by methanol production in $\Delta t$ \\
\hline 26 & $n_{r H}$ & Hydrogen consumption by fuel cell in $\Delta t$ \\
\hline 27 & $n_{r O}$ & Oxygen consumption by fuel cell in $\Delta t$ \\
\hline 28 & $n_{\Delta H}$ & Hydrogen consumption amount in $\Delta t$ \\
\hline 29 & $n_{\Delta O}$ & Oxygen consumption in $\Delta t$ \\
\hline 30 & $n_{\Delta H}^{\prime}$ & Hydrogen amount when the pressure of the hydrogen tank is over the upper limit \\
\hline 31 & $n_{\Delta O}^{\prime}$ & Oxygen amount when the pressure of the oxygen tank is over the upper limit \\
\hline 32 & $N_{e}$ & The serial units of fuel cells \\
\hline 33 & $N_{f_{c}}$ & Flow rate of the hydrogen fed in the fuel cells \\
\hline 34 & $N_{H_{2}}$ & Hydrogen flow rate in water electrolysis \\
\hline 35 & $\mathrm{~N}_{\mathrm{H}_{2} \mathrm{O}}$ & Flow rate of the hydrogen by water electrolysis \\
\hline 36 & $N_{m h g}$ & Hydrogen flow rate consumed by methanol production at the rated power \\
\hline 37 & $N_{r H \_ \text {max }}$ & Hydrogen consumption at full discharging of the fuel cells \\
\hline 38 & $N_{r H \_ \text {min }}$ & Hydrogen flow rate when fuel cell discharging in minimum \\
\hline 39 & $p_{\text {cap }}$ & Tank pressure when fully charged \\
\hline 40 & $p_{f_{\mathcal{C}} H}$ & Hydrogen pressure in a fuel cell \\
\hline 41 & $p_{f c_{-} \max }$ & Maximum power output of fuel cell discharging \\
\hline 42 & $p_{f C_{-} \min }$ & Minimum power output of fuel cell discharging \\
\hline 43 & $p_{f c_{-} O}$ & Oxygen pressure in a fuel cell \\
\hline 44 & $p_{\text {Hcap }}$ & Full pressure of the hydrogen tank \\
\hline 45 & $p_{\text {Hre }}$ & Current pressure in the hydrogen tank \\
\hline 46 & $p_{H \_0}$ & Initial pressure in hydrogen tank \\
\hline 47 & $p_{\text {Ocap }}$ & Full pressure of the oxygen tank \\
\hline 48 & pre & Current pressure in the oxygen tank \\
\hline 49 & $p_{O \_} 0$ & Initial pressure in oxygen tank \\
\hline 50 & $p_{\text {vre }}$ & Current pressure in storage tank \\
\hline 51 & $P_{f_{c}}$ & Discharging power of fuel cell \\
\hline 52 & $P_{\mathrm{H}_{2} \mathrm{O}}$ & Power for water electrolysis \\
\hline 53 & $P_{j h}$ & Cluster power demand dispatched by cluster control center \\
\hline
\end{tabular}


Table A1. Cont.

\begin{tabular}{lll}
\hline 54 & $P_{\text {load }}$ & Local power demand \\
55 & $P_{m h g}$ & $\begin{array}{l}\text { Equivalent power for the water electrolysis when the amount of the hydrogen } \\
\text { production is equal to the amount of methanol production }\end{array}$ \\
56 & $P_{S}$ & Fed-in power to the grid \\
57 & $P_{\text {wind }}$ & Wind power \\
58 & $R$ & Idea fuel constant $(8.3145 \mathrm{~J} / \mathrm{mol} \cdot \mathrm{K})$ \\
59 & $T$ & Nominal temperature of fuel cell \\
60 & $T_{H}$ & Temperature in hydrogen tank \\
61 & $T_{O}$ & Temperature in oxygen tank \\
62 & $U_{c}$ & Equivalent voltage \\
63 & $U_{c e l l}$ & Output voltage of a single fuel cell \\
64 & $U_{f c}$ & Discharging voltage of fuel cell \\
65 & $U_{\text {ohmic }}$ & Polarization voltage \\
66 & $V_{\text {Hcap }}$ & Volume capacity of the hydrogen tank \\
67 & $V_{\text {Ocap }}$ & Volume capacity of the oxygen tank \\
68 & $V_{a}$ & Size of a single fuel cell \\
69 & $V_{c a}$ & Cathode size of a single fuel cell \\
70 & $V_{m}$ & Molar volume \\
71 & $Z_{m}$ & Equivalent resistance of the membrane \\
72 & $Z_{c}$ & Equivalent resistance of a fuel cell \\
73 & $\varepsilon_{1}, \varepsilon_{2}, \varepsilon_{3}$, & Empirical coefficients \\
74 & $\varepsilon_{4}$ & Efficiency of water electrolyser \\
75 & $\eta_{e}$ & Discharging efficiency of fuel cell \\
76 & $\eta_{f}$ & Resistant rate of the membrane \\
77 & $\rho_{M}$ & Water rate of the membrane \\
78 & $\Delta p_{H \_1}$ & Hydrogen pressure increment by water electrolysis \\
79 & $\Delta p_{H_{-} 2}$ & Hydrogen pressure increment by incomplete consumption by fuel cell \\
80 & $\Delta p_{H \_3}$ & Hydrogen pressure decrement by methanol production \\
81 & $\Delta p_{H \_4}$ & Hydrogen pressure decrement by fuel cell consumption \\
82 & $\Delta t$ & Operational time interval \\
\hline & & \\
& &
\end{tabular}

\section{References}

1. Shu, Y.B. Deepening Cooperation, Embrace Challenges to Promote Sustainable Development of Renewable Energy. In Proceedings of the 2017 International Conference on Renewable Energy Development and Technology and High-Level Dialogue, Frankfurt, Germany, 16 June 2017; Available online: http: / /www. epri.sgcc.com.cn/html/eprien/col2016201124/2017-07/03/20170703161018331376621_1.html (accessed on 10 July 2017).

2. Zhao, H.; Wu, Q.; Hu, S.; Xu, H. Review of energy storage system for wind power integration support. Appl. Energy 2015, 137, 545-553. [CrossRef]

3. Perera, A.; Vahid, M.; Mauree, D.; Scartezzini, J. Electrical hubs: An effective way to integrate non-dispatchable renewable energy sources with minimum impact to the grid. Appl. Energy 2017, 190, 232-248. [CrossRef]

4. Solomon, A.; Kammen, D.; Callaway, D. Investigating the impact of wind-solar complementarities on energy storage requirement and the corresponding supply reliability criteria. Appl. Energy 2016, 168, 130-145. [CrossRef]

5. Shi, J.; Tang, Y.J.; Ren, L.; Li, J.D. Application of SMES in wind farm to improve voltage stability. Phys. C Supercond. Appl. 2008, 15, 2100-2103. [CrossRef]

6. Li, N.; Zhang, X.L.; Shi, M.J.; Zhou, S.L. The prospects of China's long-term economic development and $\mathrm{CO}_{2}$ emissions under fossil fuel supply constraints. Resour. Conserv. Recycl. 2017, 121, 11-22. [CrossRef]

7. Shekhar, C.C. Methanol: The New Hydrogen, MIT Technology Review. Available online: https://www. technologyreview.com/s / 405597/methanol-the-new-hydrogen/ (accessed on 10 July 2017).

8. Li, Q.; Wei, Y.N.; Chen, Z.A. Water-CCUS nexus: Challenges and opportunities of China's coal chemical industry. Clean Technol. Environ. Policy 2016, 18, 775-786. [CrossRef]

9. Khaitan, S.K.; Raju, M.; McCalley, J.D. Design of a novel and efficient hydrogen compressor for wind energy based storage systems. Int. J. Hydrog. Energy 2015, 40, 1379-1387. [CrossRef] 
10. Lotfy, M.E.; Senjyu, T.; Farahat, M.A.; Abdel-Gawad, A.F.; Yona, A. A frequency control approach for hybrid power system using multi-objective optimization. Energies 2017, 10, 80. [CrossRef]

11. Maleki, A.; Hafeznia, H.; Rosen, M.A.; Pourfayaz, F. Optimization of a grid-connected hybrid solar-windhydrogen CHP system for residential applications by efficient metaheuristic approaches. Appl. Therm. Eng. 2017, 123, 1263-1277. [CrossRef]

12. Beccali, M.; Brunone, S.; Finocchiaro, P. Method for size optimisation of large wind-hydrogen systems with high penetration on power grids. Appl. Energy 2013, 102, 534-544. [CrossRef]

13. Chrenko, D.; Lecoq, S.; Herail, E. Static and dynamic modeling of a diesel fed fuel cell power supply. Int. J. Hydrog. Energy 2010, 35, 1377-1389. [CrossRef]

14. Boulon, L.; Agbossou, K.; Hissel, D. A macroscopic PEM fuel cell model including water phenomena for vehicle simulation. Renew. Energy 2012, 46, 81-91. [CrossRef]

15. Jiang, Z.H.; Yu, X.W. Modeling and control of an integrated wind power generation and energy storage system. In Proceedings of the Power \& Energy Society General Meeting 2009, Calgary, AB, Canada, 26-30 July 2009; pp. 1-8.

16. Abbey, C.; Joos, G. Supercapacitor Energy Storage for Wind Energy Applications. IEEE Trans. Ind. Appl. 2007, 43, 769-776. [CrossRef]

17. Ni, W.D.; Gao, J.; Chen, Z.; Li, Z. How to make the production of Methanol/DME “GREENER"-The integration of wind power with coal chemical industry. Front. Energy Power Eng. 2009, 3, 94-98. (In Chinese) [CrossRef]

18. Yuan, T.; Lin, K.; Guan, Y.; Dong, X.; Sun, Y.; Mei, S. Modeling on hydrogen producing progress in EMR based wind power-hydrogen energy storage and coal chemical pluripotent coupling system. High Volt. Eng. 2015, 41, 2156-2164. (In Chinese)

19. Elgammal, A.A.A.; El-naggar, M.F. MOPSO-based optimal control of shunt active power filter using a variable structure fuzzy logic sliding mode controller for hybrid (FC-PV-Wind-Battery) energy utilisation scheme. IET Renew. Power Gener. 2017, 11, 1148-1156. [CrossRef]

20. Saravanan, S.; Thangavel, S. Instantaneous reference current scheme based power management system for a solar/wind/fuel cell fed hybrid power supply. Int. J. Electr. Power Energy Syst. 2014, 55, 155-170. [CrossRef]

21. Mohammadi, S.; Soleymani, S.; Mozafari, B. Scenario-based stochastic operation management of MicroGrid including Wind, Photovoltaic, Micro-Turbine, Fuel Cell and Energy Storage Devices. Int. J. Electr. Power Energy Syst. 2014, 54, 525-535. [CrossRef]

22. Xu, L.J.; Fan, X.C.; Wang, W.Q. Renewable and sustainable energy of Xinjiang and development strategy of node areas in the "Silk Road Economic Belt". Renew. Sustain. Energy Rev. 2017, 79, 274-285. [CrossRef]

23. National Energy Administration, Chinese. Energy Development 12th Five-Year Plan. Available online: http:/ / www.nea.gov.cn/2013-01/28/c_132132808.htm\# (accessed on 1 January 2013).

24. Xinhua. China Tops the World in Renewable Energy Production: BP Report. Available online: http: / / news.xinhuanet.com/english/2017-07/10/c_136432582.htm (accessed on 10 July 2017).

25. Lin, H.; Jin, H.G.; Gao, L.; Han, W. Economic analysis of coal-based polygeneration system for methanol and power production. Energy 2010, 35, 858-863. [CrossRef]

26. Tang, L.; Wu, J.Q.; Yu, L.; Bao, Q. Carbon emissions trading scheme exploration in China: A multi-agent-based model. Energy Policy 2015, 81, 152-169. [CrossRef]

27. Jia, L.; Qu, F.C. Index of Carbon Dioxide and the Main Pollutant Emissions of Coal Chemical Industry Demonstration Project Research. Chem. Ind. 2014, 7, 13-17. (In Chinese)

28. Lamy, C. From hydrogen production by water electrolysis to its utilization in a PEM fuel cell or in a SO fuel cell: Some considerations on the energy efficiencies. Int. J. Hydrog. Energy 2016, 41, 15415-15425. [CrossRef]

29. Giaconia, A.; Grena, R.; Lanchi, M.; Liberatore, R.; Tarquini, P. Hydrogen/methanol production by sulfur-iodine thermochemical cycle powered by combined solar/fossil energy. Int. J. Hydrog. Energy 2007, 32, 469-481. [CrossRef]

30. Wang, W.L.; Wang, D.; Jia, H.J.; He, G.X.; Hu, Q.; Sui, P.C.; Fan, M.H. Performance Evaluation of a Hydrogen-Based Clean Energy Hub with Electrolyzers as a Self-Regulating Demand Response Management Mechanism. Energies 2017, 10, 1211. [CrossRef]

31. Francois, B.; Hissel, D.; Iqbal, M.T. Dynamic Modelling of a Fuel Cell and Wind Turbine DC-Linked Power System. In Proceedings of the ELECTRIMACS Conference, Hammamet, Tunisia, 17-20 April 2005; The ELECTRIMACS Technical Committee: Hammamet, Tunisia, 2005. 
32. Choi, S.; Chu, K.; Ryu, J.; Sunwoo, M. Empirical modeling of a polymer electrolyte fuel cell based on water transport investigation and current interrupt measurement. Int. J. Automot. Technol. 2009, 10, 719-732. [CrossRef]

33. Mann, R.F.; Amphlett, J.C.; Hooper, M.A.I.; Jensen, H.M.; Peppley, B.A.; Roberge, P.R. Development and application of a generalised steady-state electrochemical model for a PEM fuel cell. J. Power Sources 2000, 86, 173-180. [CrossRef]

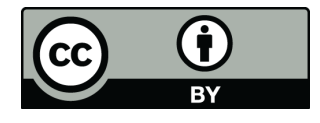

(C) 2017 by the authors. Licensee MDPI, Basel, Switzerland. This article is an open access article distributed under the terms and conditions of the Creative Commons Attribution (CC BY) license (http:/ / creativecommons.org/licenses/by/4.0/). 